\title{
Moral Quality in Adjudication: On Judicial Virtues and Civic Friendship
}

\author{
Iris van Domselaar
}

'Occasion by occasion, one knows what to do, if one does, not by applying universal principles, but by being a certain kind of person: one who sees situations in a certain distinctive way.'

\section{Introduction $^{2}$}

We do not need to be legal professionals to know that the quality of adjudication matters a lot to citizens who are involved in a legal proceeding and that this quality may not too easily be assumed. Public sources like films, literature, documentaries, YouTube clips, and news broadcasting - or perhaps our own experience with legal proceedings - confront us with the fact that the topic of quality is an urgent one.

This article is premised on the idea that in order for the practice of adjudication to be legitimate it must possess moral quality, it must be a practice in which judges see to it that citizens who participate in a legal proceeding receive their due. If we indeed agree on this point, it makes sense to distinguish two ways of realizing moral quality. The first is an 'outside in' approach, which realizes moral quality primarily by means of external, explicit standards, such as rules, precedents, doctrine, and moral background principles of law. The second is an 'insideout' approach. ${ }^{3}$ This approach understands moral quality above all through the person of the judge, the one who is responsible for giving citizens their due.

As a contribution to the ever more blooming tradition of virtue-jurisprudence, this article proposes an 'inside-out' approach, that is, a specific version of a virtue-centred approach to adjudication. It holds that for adjudication to have moral quality judges must have, at least to a sufficient degree, a six-pack of judicial virtues (section 2). At the same time it will be argued that for a virtue-centred approach to be legitimate it cannot stand on its own. In order to account for moral quality it needs to be complemented by the concept of civic friendship (sec-

* This article is based on chapter 10 and chapter 11 of my dissertation. See Iris van Domselaar, The Fragility of Rightness. Adjudication and the Primacy of Practice ( $\mathrm{PhD}$ thesis, University of Amsterdam, 2014).

1 John McDowell, 'Virtue and Reason,' in Mind, Value and Reality, ed. John McDowell (Cambridge, MA: Harvard University Press, 1998), 73.

2 I am grateful for the valuable comments of two anonymous reviewers and for the remarks of Antony Duff, the editor of this journal. Also, I am indebted to the participants of the Legal Reasoning, Virtue and Politics Workshop which was held on 13-14 June 2014 at the University of Edinburgh Law School for their penetrating criticism and suggestions on an earlier draft. For this distinction I took inspiration from McDowell, 'Virtue and Reason,' 50. 
tion 3). If citizens who participate in a legal proceeding are to be given their due, adjudication must not only be a practice constituted by the 'beings and doings' of (sufficiently) virtuous judges. These judges should in addition address the case at hand as a civic friend. The article ends with some concluding remarks (section 4).

\section{Moral quality of adjudication as a six-pack of judicial virtues}

The approach to moral quality of adjudication that is presented below is meant as a contribution to the emerging field of 'virtue-jurisprudence,' a field of legal scholarship that connects the concept of virtue to law. ${ }^{4}$ I will defend a specific version of a virtue-centred approach, one that gives primacy to a particular set of judicial virtues. $^{5}$

Virtues are character-traits, stable dispositions, or 'reliable sensitivities' of agents. ${ }^{6} \mathrm{~A}$ virtue is a condition due to which a person is disposed to act and feel in a certain way. They are personal excellences, which are 'well entrenched in its possessor (...), unlike a habit such as being a tea-drinker (...)”, as Rosalind Hursthouse says. ${ }^{7}$ Of course, this is not to say that virtues are fixed, rigid or mechanical states. Far from that: virtues always contain an element of freedom,

4 See for an elaborate introduction to and overview of this tradition Amalia Amaya and Ho Hock Lai, 'Of Law, Virtue and Justice: An introduction,' in Law, Virtue and Justice, ed. Amalia Amaya et al. (Oxford: Hart Publishing, 2013). See for other versions of a virtue-centred approach to adjudication Lawrence B. Solum, 'Virtue Jurisprudence: A Virtue-Centered Theory of Judging,' Metaphilosophy 34(1/2 (2003); Lawrence B. Solum, 'Virtue Jurisprudence: Towards an Aretaic Theory of Law,' in Aristotle and the Philosophy of Law: Theory, Practice and Justice, ed. Liesbeth HuppesCluysenaer et al. (Dordrecht: Springer, 2013); Amalia Amaya, 'Virtue and Reason in Law' (Coyoacán: UNAM Philosophical Research Institute, 2012).

5 A virtue-centred approach to adjudication is typically based on a fundamental critique on rule- or principle-based approaches to adjudication. It can be summarized as follows: (1) Rules or principles offer too under-determinate and conflicting a viewpoint to 'guide' the reasoning of agents. (2) As particulars will always come in different, unique constellations that are unfathomable and not determinable in advance, rules, principles and other kinds of explicit general precepts can never fully take stock of all that might be relevant in a concrete legal case. Within the scope of this article this critique and its exact merits will not be further elaborated.

6 McDowell, 'Virtue and Reason,' 51.

7 Rosalind Hursthouse, 'Virtue Ethics', in The Stanford Encyclopedia of Philosophy ed. Edward N. Zalta (Stanford: Stanford University, 2013). This aspect, the virtues as character traits, is vital for appreciating the force of the situationists' critique on virtue ethics. Situationists argue that robust character traits do not exist because people are too inconsistent from one situation to another for such traits to play a role in the explanation of behaviour. Here I will not delve into the debate between virtue ethicists and situationists. See for the situationists' critique on virtueethics: Gilbert Harman, 'Moral Philosophy Meets Social Psychology: Virtue Ethics and the Fundamental Attribution Error,' Proceedings of the Aristotelian Society 99 (1999); John M. Doris, Lack of Character (Cambridge: Cambridge University Press, 2002); Owen Flanagan, Varieties of Moral Personality: Ethics and Psychological Realism (Cambridge, MA: MIT Press, 1991). See for strong replies to this critique: Julia Annas, 'Comments on John Doris's "Lack of Character,"' Philosophy and Phenomenological Research 71 (2005): 636-42; John Sabini and Mauri Silver, 'Lack of Character: Situationism Critiqued,' Ethics (2005); Gopal Sreenivasan, 'Errors about Errors: Virtue Theory and Trait Attribution,' Mind 111(442) (2002); Joel J. Kupperman, 'The Indispensability of Character.' Philosophy 76 (2001): 239-50. 
reflection, and choice. Being virtuous is the way a person chooses to be. Virtues are developed through repeated choices and their actual exercise also has a dimension of choice in it. ${ }^{8}$

In order to have any substantive meaning a virtue-ethical approach to adjudication must offer an account of which virtues are needed for judges to live up to the demands of their role. For the determination of these virtues I do not use an analytical method, deducing these virtues from prior abstract axioms. Rather I take, as it were, a quasi-phenomenological route and try to stay close to knowledge embedded in practice. In a neo-Aristotelian vein I draw on the views of 'the many and the wise' - on the endoxa as Aristotle would qualify them. ${ }^{9}$ This method is premised on the idea that expressions of locally embedded insights of normal people and of experts, in our case of legal practitioners and legal scholars, do contain at least some truth. ${ }^{10}$

On the basis of these endoxa I propose a specific set of judicial virtues as indispensible for realizing moral quality in adjudication. These are the professional character-traits that judges need for realizing the good that their role is to serve, i.e. to give citizens who participate in a legal proceeding their due. ${ }^{11}$ These virtues are not unique in the sense that they are exclusively relevant for adjudication, as a sui generis practice. Some of these judicial virtues are in fact elaborations of the cardinal virtues: practical wisdom, courage, temperance, and justice, which throughout history and across different cultures and countries are held to be necessary for all kinds of social practices. ${ }^{12}$

Tailored to the specific judicial context these virtues are pertinent for adjudication as well, being a social practice par excellence. Hence it is no surprise that

8 As Julia Annas put it: 'being virtuous is the way I have made myself, the way I have chosen to be, and in deciding in accordance with it, I endorse the way I have become.' Cf. Julia Annas, The Morality of Happiness (Oxford: Oxford University Press, 1993), 10.

9 Aristotle describes his method as follows: 'I shall thus take into account the things people say about it: for a true view will have all the available evidence in harmony with it, while a false one quickly finds itself in discord with what is true.' Aristotle, 'Nichomachean Ethics,' in Nicomachean Ethics: Translation, Introduction, and Commentary, ed. Sarah Broadie et al. (Oxford: Oxford University Press, 2002), 1098b10-12.

10 John M. Cooper, Reason and Emotion. Essays on Ancient Moral Psychology and Ethical Theory (Princeton, NJ: Princeton University Press, 1999), 288.

11 A specific feature of a profession in contrast with an occupation is that it is to serve some public good. A crucial question for any virtue-ethical approach to professional roles will therefore be what sort of dispositions help a professional realize the good that the profession is to serve. See Justin Oakley and Dean Cocking Virtue Ethics and Professional Roles (Cambridge: Cambridge University Press, 2001), 92.

12 Cf. Christopher Peterson and Seligman, Character Strengths and Virtues (Oxford: Oxford University Press, 2004); Julia Annas, 'Being Virtuous and Doing the Right Thing,' Proceedings and Addresses of the American Philosophical Association 78(2) (2004). 
some of them are - albeit sometimes differently pigeonholed - laid down in national and international guidelines of judicial ethics for judges. ${ }^{13}$

As we shall see, the other two virtues that are proposed are most distinctly judicial virtues as they are intimately related to the institutional role of the judiciary in a constitutional democracy: to resolve conflicts that arise among citizens and between citizens and the state on the basis of settled law.

On the basis of this dialectical method we can identify the following six-pack of judicial virtues as indispensible for realizing moral quality in adjudication: judicial perception, judicial courage, judicial temperance, judicial justice, judicial impartiality and judicial independency. ${ }^{14}$ Due to the scope of this article, I will only briefly discuss each of them. It goes without saying that each of these virtues deserves a more thorough exploration. ${ }^{15}$

Judicial perception. ${ }^{16}$ A defining feature of the present virtue-ethical approach is that it sees the virtue of judicial perception as key for realizing moral quality. This also, because it is a judicial virtue that pervades all the others. The importance of this virtue is due to the fact that adjudication is a practice that deals with individual cases and thus with particulars. These particulars neither impose themselves on the judge's mind, nor do they jump into his sight of their own accord. ${ }^{17}$ So, in order to be adequately grasped human effort is needed. In addition, particulars will always come in different, unique constellations that are

13 Albeit sometimes under the heading of another term, such as 'values' or 'competences.' See for instance: 'The Bangalore Principles of Judicial Conduct' (The Hague: UN Judicial Group on Strengthening of Judicial Integrity, 2002); 'Judicial Ethics Report 2009-2010: Judicial Ethics, Principles, Values and Qualities’ (Europe: Working Group European Network of Councils for the Judiciary, 2009); 'Magna Carta of Judges (Fundamental Principles)' (Brussels: Consultative Council of European Judges, 2010); 'NVvR Guide to Judicial Conduct' (Netherlands: The Dutch Association for the Judiciary, 2011).

14 In the professional journal of the Dutch judiciary 'Rechtstreeks' I will also argue for this six-pack of judicial virtues.

15 For instance, one question that should be thoroughly addressed for each of these virtues separately is which kind(s) of problem(s) such a virtue aims to solve.

16 For this discussion of judicial perception I primarily draw on neo-Aristotelian accounts of practical wisdom that in particular focus on Aristotle's concept of aisthesis (perception), on Iris Murdoch's account of 'moral vision' and on works of others that are inspired by this latter account. A salient difference between the two traditions is that in neo-Aristotelian accounts of practical wisdom perception is directly linked to action, whereas in Murdoch's account it is not. In Murdoch's work perception is a moral capacity that is relevant for and at work in all kinds of responses other than mere action or decision-making. For an illuminating and deep discussion of the two conceptions of moral perception, see Bridget Clarke, The Lens of Character: Aristotle, Murdoch, and the Idea of Moral Perception, (PhD thesis, University of Pittsburgh, 2003). See for neo-Aristotelian discussions of the relation between perception and particulars also David Wiggins, 'Deliberation and Practical Reason,' in Essays on Aristotle's Ethics, ed. Amélie O. Rorty (Berkeley: University of California Press, 1980); McDowell, 'Virtue and Reason'; Martha C. Nussbaum, 'The Discernment of Perception: An Aristotelian Conception of Private and Public Rationality,' in Love's Knowledge: Essays on Philosophy and Literature (Oxford: Oxford University Press, 1990). 
unfathomable and not determinable in advance. ${ }^{18}$ Therefore prior explicit standards such as codified rules and principles can never be used as an exhaustive measure where practical matters are concerned. Not in the least also because of the inescapable vicious circle to which the Legal Realists already drew our attention: in order to know what the relevant legal facts are, the judge needs some kind of rule, but to know which rule is relevant, he needs to know which facts are relevant. ${ }^{19}$ Taken together these insights lead us to the conclusion that judges inherently have substantive freedom to select, establish, and give legal weight to the facts of a legal case, and thus, by implication, that the person of the judge plays an important role in the outcome of a legal case.

If we want to steer clear of a subjectivist account of adjudication, of the idea that 'anything goes, ${ }^{20}$ we should establish under which conditions we have reason to think that judges are nonetheless capable to adequately grasp and respond to these particulars. It is to this question that the virtue of judicial perception is to be an answer. In order for the judge to be able to recognize, to select, to grasp and to know how best to respond to them, a judge must sufficiently possess the capacity of judicial perception, a species of ethical perception. It was Aristotle who first elaborated the fact that particulars pertain to the domain of perception, that they are not the 'object of systematic knowledge, but of perception.' ${ }^{21}$ In the literature ethical perception has also been coined as 'perceptual capacity,'22 'situa-

18 Cf. Aristotle, 'Nichomachean Ethics,' 1104a1-10; Nussbaum, 'The Discernment of Perception: An Aristotelian Conception of Private and Public Rationality, 66-75; Wiggins, 'Deliberation and Practical Reason,' 233.

19 Cf. Jerome Frank, Law and the Modern Mind (New York: Brentano's Publisher, 1931), 116.

20 A virtue-ethical approach thus aims to meet Jerome Frank's concern that a judge has the freedom to select and establish the facts such that his legal arguments lead to the decision that he intuitively favoured from the start (his 'hunch') and for whatever reason that pleases him. Frank has eloquently stressed this point where he states that ' $\mathrm{t}]$ he judge, in arriving at this hunch, does not nicely separate his belief as to the "facts" from his conclusion as to the "law"; his general hunch is more integral and composite, and affects his report - both to himself and to the public concerning the facts.' Cf. Frank, Law and the Modern Mind, 116. See for discussions about the (intimate) relation between facts and rules in the process of legal reasoning and the resulting 'discretion' of the judge by Dutch legal theorists P. Scholten, ed., Mr. C. Asser's Handleiding tot de Beoefening van het Nederlands Burgerlijk Recht (Zwolle: W.E.J. Tjeenk Willink, 1974), § 26; J.B.M. Vranken, ed., Asser-Vranken (Algemeen Deel) (Zwolle: W.E.J. Tjeenk Willink, 1995); G.J. Wiarda, Drie typen van rechtsvinding (Deventer: W.E.J. Tjeenk Willink, 1999); Carel E. Smith, Regels van rechtsvinding (Den Haag: Boom Juridische uitgevers, 2005), 82-86; Carel E. Smith, Feit en rechtsnorm. Een methodologische studie naar de betekenis van de feiten voor de rechtsvinding en de legitimatie van het rechtsoordeel (Maastricht: Shaker, 1998).

21 Aristotle, 'Nichomachean Ethics,' 1142a27-281; Wiggins, 'Deliberation and Practical Reason,' 233.

22 McDowell, 'Virtue and Reason,' 51. 
tion sense, ${ }^{23}$ 'situational appreciation'24 and 'vision, ${ }^{, 25}$ qualifications that - not without reason - all refer to the idea of sense-perception. ${ }^{26}$

Similar to sense-perception ethical perception allows an agent to have access and gain understanding of ethical reality. ${ }^{27}$ In the same way that sense-perception 'shows' a dress to be 'really' red, ethical perception can show a situation or action to be 'really' discriminatory. It thus implies a claim to objectivity. Yet, this claim to objectivity is not deduced from a reliance on an external independent ethical world containing brute ethical facts that are waiting to be discovered. It implies a conception of ethical reality that is construed by a complex interplay between on the one hand an agent who possesses the sensitivity to perceive well and on the other the external world. Thus, in this conception this external world is, in the words of John Mc Dowell, 'not brutely there - not there independently of our sensibility - any more than colours are (...).'28

This sensibility in turn does not stand on its own; it depends heavily on the availability of a range of 'thick' or 'entangled' value concepts, concepts that can be applied in a more or less immediate way because of their substantial empirical content. ${ }^{29}$ At the same time their application entails an evaluative attitude towards the object so described. ${ }^{30}$ Think for instance of concepts like racism, courage, poverty, neglect, honesty, and violence. If a judge 'sees' that a thick value concept applies, he will not need to separately add an evaluation, as this very valuation cannot be 'peeled' off from the description 'so as to stand as independently comprehensible. ${ }^{31}$ Without such concepts ethical perception would remain without any import. ${ }^{32}$

23 Karl Llewellyn, The Common Law Tradition: Deciding Appeals (Boston: Little, Brown, 1960), 59-61, 121-57, 206-8, as cited in Solum, 'Virtue Jurisprudence. A Virtue-Centered Theory of Judging,' 192.

24 Wiggins, 'Deliberation and Practical Reason,' 233.

25 Iris Murdoch, 'Vision and Choice,' in Existentialists and Mystics: Writings on Philosophy and Literature, ed. Peter Conradi (Harmondsworth: Penguin Books, 1997), 83-84.

26 By sense-perception I mean 'the awareness or apprehension of things by sight, hearing, touch, smell and taste.' Cf. <http://plato.stanford.edu/entries/perception-problem/>.

27 For this discussion of objectivity in relation to ethical perception I draw on Clarke, The Lens of Character, 27-28.

28 McDowell, 'Values and Secondary Qualities,' 146.

29 See for a description of thick concepts: Hilary Putnam, The Collapse of the Fact/Value Dichotomy and Other Essays (Cambridge, MA: Harvard University Press, 2002), 34-45; Bernard Williams, Ethics and the Limits of Philosophy (Cambridge, MA: Harvard University Press, 1985) 129, 140.

30 Cf. Jonathan Dancy, 'In Defence of Thick Concepts,' Midwest Studies In Philosophy 20(1) (1995): 263.

31 Dancy, 'In Defence of Thick Concepts,' 263.

32 See for this point also Lawrence Blum, 'Moral Perception and Particularity,' Ethics 101(4) (1991): 707. 
The analogy with sense-perception is fitting also because - as a well-developed sensitivity - ethical perception has a strong affective and emotional side to it. ${ }^{33}$ The kind of knowledge that ethical perception produces is therefore far from 'cool' or 'detached.' A judge who possesses the capacity of judicial perception will typically have a vivid understanding of the cases he is confronted with.

Despite said similarities, it is important to stress that ethical perception is not a species of sense-perception as important differences exists between them. For one, sense-perception points to either a capacity that anyone with basic rational capacities possesses (simple perception) or to a capacity that one can acquire by developing certain cognitive skills (technical perception). ${ }^{34}$ Both kinds of senseperception are character-independent. A sadist and an altruist are equally equipped to discern that a dress is 'really' red (simple perception) or that a certain form is a triangle (technical perception).

Ethical perception, by contrast, involves the personality of the agent. In the words of Martha Nussbaum ethical perception is '(...) a complex response of the entire personality, an appropriate acknowledgment of the features of the situation on which action is to be based, a recognition of the particular. 35 By implication, only if one's character is of a certain quality will one be able to grasp the ethical professional character of the judge. Conversely, a flaw in a judge's character can 'block' him from adequately taking in the facts, from getting in touch with the reality he is confronted with. ${ }^{36}$

For instance, a judge who suffers from mysophobia may not be able to adequately assess whether the hygienic condition of the housing situation of a psychiatric patient is such that it warrants compelled admission to a psychiatric hospital because of 'serious neglect.'

In order to more fully grasp the bearing of judicial perception as a central judicial virtue, one more issue must be addressed. It may be objected that it does not require a virtue-ethical approach to adjudication to acknowledge that judges need a special capacity in order to be able to adequately deal with the particular. For this capacity has in fact been acknowledged - albeit not very prominently within (Kantian) rule- or principle-based approaches to ethics and adjudication under the heading of 'judgment.' Kant for instance states that '[i]t is obvious that between theory and practice there is required (...) an act of judgment by which a practitioner distinguishes whether or not something is a case of the rule (...). ${ }^{37}$

33 The approach to adjudication that is defended thus relies on the idea that emotions can have cognitive content, and that cognition itself hinges on the emotive capacities of an agent. For this point I follow Martha Nussbaum's views on the cognitive value of emotions. Cf. Nussbaum, 'The Discernment of Perception,' 75-82. An important question that I will need to address in further work on the notion of judicial perception is how emotion and perception precisely relate within this virtue.

34 Cf. Clarke, The Lens of Character, 29.

35 Martha C. Nussbaum, The Fragility of Goodness: Luck and Ethics in Greek Tragedy and Philosophy, Rev. ed. (New York: Cambridge University Press, 2001 (1986)), 309.

36 This is not to deny that one can be wrong about the moral bearing of a situation for reasons other than a character flaw. Cf. Blum, 'Moral Perception and Particularity,' 704.

37 Mary J. Gregor, ed., Immanuel Kant. Practical Philosophy, The Cambridge Edition of the Works of Immanuel Kant (New York: Cambridge University Press, 1996), 279. 
So, it remains to be seen whether judicial perception has something new to offer in this regard.

I think it does. Often in rule- or principle-based approaches to ethics and adjudication 'judgment' is presented as an exclusively intellectual capacity that on the basis of a set of value-neutral and well-defined 'facts' is to determine the practical implication of a general rule or principle. In this interpretation judgment boils down to a character-independent activity, an activity for which all agents with certain intellectual capacities and with a certain theoretical knowledge are equally positioned. ${ }^{38}$

However, as already pointed out, judicial perception involves more than the use of intellect; being a species of ethical perception it is an activity in which character is involved. It thus assumes that the concepts that are applied are characterdependent in that the agent works through them, as it were, and that this application inevitably has a personal character. ${ }^{39}$

In addition, judicial perception is not merely about determining the practical implication of a general rule or principle for a concrete case. It also encompasses an ability that is antecedent to judgment, i.e. the ability to recognize which facts are legally relevant and which of them exactly 'pull' to certain legal rules and principles. ${ }^{40}$

Also, whereas the notion of judgment is linked to that of the application of rules and principles leading to concrete judicial decisions, judicial perception sometimes takes place outside the context of legal rules and rule application altogether and as such provides a judge with reasons to respond in a certain way (for instance to show empathy in a court session or in a sentence) other than in the form of a judicial decision. Judicial perception and its expression can be valuable in their own right. We have reason to praise the correct perception by a judge as a way of honouring the particular, regardless of its leading to a right judicial decision. ${ }^{41}$

Although judicial perception is key to the list of judicial virtues, it is surely not the only professional virtue a judge needs in order to give the citizens involved in a legal proceeding their due. This requires other judicial virtues as well.

Here judicial courage kicks in as a cardinal virtue that the judge needs. ${ }^{42}$ Since the beginning of Western moral philosophy courage has been acknowledged as a cardinal virtue, as a necessary condition for a good life and for a just society. Within classic Greek thought the situation of war is considered the fitting context for

38 Cf. Clarke, The Lens of Character, 38.

39 Cf. Clarke, The Lens of Character, 17.

40 Cf. Blum, 'Moral Perception and Particularity,' 711.

41 Cf. Blum, 'Moral Perception and Particularity,' 713.

42 See for a general account of courage Nelson H. Goud, 'Courage: Its Nature and Development,' Journal of Humanistic Counselling, Education and Development 44 (2005); Doublas N. Walton, Courage: A Philosophical Investigation (Berkeley: University of California Press, 1986). See for a discussion of the importance of courage in the Dutch (judicial) context: Marc Loth, 'De goede jurist. Over morele moed, onafhankelijkheid en een riskante omgeving,' in Code en karakter. Beroepsethiek in onderwijs, jeugdzorg en recht, ed. Jos Kole and Doret de Ruyter (Amsterdam: SWP Uitgeverij, 2009); Iris van Domselaar, 'Over professionele moed,' Openbaar Bestuur 23(2) (2013). 
courage; the prototype of a courageous person is the war hero who, battling with the enemy, is able to overcome his fear of death. ${ }^{43}$ In this interpretation courage has a rather outspoken martial and masculine bearing.

Immanuel Kant famously emphasized the intellectual dimension of courage. For him courage is the ability to think for one self and to act accordingly. 'Sapere Aude! Have courage to make use of your own understanding!,' he states. ${ }^{44}$ Here the prototype of a courageous person is not so much the war hero, but rather the one who dares to speak up in public life. For Kant courage points to the ability to overcome 'amour propre,' the broadly shared human desire to be liked by others. What does judicial courage mean in the context of adjudication in a Western constitutional order? The natural context for judicial courage consists of legal cases and situations in which the judge faces personal risks if he does the right thing. One could think of situations in which a judge by acting rightly risks to lose certain career opportunities, will be more likely to receive criticism from his colleagues or from the public at large, or can expect to experience an urgent sense of insecurity because of the severe consequences of the decision he takes. ${ }^{45}$ The quality of courage enables the judge to confront and overcome threats, fears, and pressures that otherwise may bring him to not effectuate what he sees as the right thing to do. This is not the same as being reckless, stiff-necked, or being structurally disloyal to colleagues. A courageous judge simply has the inner strength to remain stoical and do his virtuous duty even if it has repercussions for him such as criticism, unpopularity, or loneliness. For instance, it may require courage for the youngest judge to be the first to speak up in a council chamber about the request for escorted leave of an inmate who is sentenced for serious sexual offences. It may be already clear for this judge that his older colleagues are most hesitant to grant such requests because of a few serious incidents that have recently occurred during such leaves, incidents that have been widely discussed in the media. In such a case a judge not only risks criticism from his colleagues, but he may also have to bear the possible consequences of successfully overriding the point of view of the others, as he cannot be sure that no incident will occur during the leave.

A judge in addition needs the virtue of judicial temperance. Temperance is a capacity of self-restraint and self-abstention that protects agents from all kinds of excesses that may occur in response to personal urges, needs, and desires and that keep them from doing the right thing. ${ }^{46} \mathrm{~A}$ judge who possesses this virtue knows how to control particular impulses stemming from his personal desires and feelings that may arise in the judicial setting. ${ }^{47}$ For instance, a temperate cal Philosophy, ed. Mary J. Gregor (Cambridge: Cambridge University Press, 1996).

45 Of course, in societies in which no stable political and social order exists and in which the judiciary is a highly politicized institution, judicial courage may also require that a judge is able to withstand even more severe personal threats in which his physical integrity as well as that of his family is at stake.

46 Cf. Peterson and Seligman, Character Strengths and Virtues, 431.

47 Cf. Aristotle, Nichomachean Ethics, 1118a24-26. 
judge does not display improper anger or inappropriate humour, nor will he behave flirtatious in court. ${ }^{48}$ Most of all this virtue implies the judge's incorruptibility, meaning that a temperate judge is not sensitive to personal and financial advantages that may result from abusing his power. A temperate judge will thus not easily end up in financial or other 'conflicts of interest, such as trading on advance knowledge of the outcome of judicial proceedings or setting a precedent that will benefit a company in which one owns stock. ${ }^{49}$

Here it is important to note that the virtue of judicial temperance is not an excuse for being a colourless or small-minded judge. From a virtue-ethical perspective we should value the fact that judges have emotions and also that they express them, lest they do so in the right way and for the right reasons. For instance, it may well be functional if a judge expresses his anger about a serious crime so as to give some extra weight to his sentence. ${ }^{50}$

Then there is the virtue of judicial justice. Justice is the most straightforwardly other regarding virtue. It can be exercised in all kinds of social practices, but its most natural context is of course that of society. Justice directly concerns the relation between the agent and society, more specifically the rights of other citizens. Judicial justice indicates that a judge is disposed to secure the values of political morality as they are worked out in settled (procedural) law, permeate the legal system and figure in society at large. ${ }^{51}$ These may, but need not be codified. It takes a just judge to know concretely which considerations of justice bear upon the case at hand and how. Only a just judge is 'ready to enter into the spirit of its requirements. ${ }^{52}$ Indeed, legal intelligence is a crucial precondition for this virtue. To adequately honour settled law and background values of political morality a judge must be learned in the sense that he must know the law thoroughly and have the analytical and cognitive skills needed to cope with complex legal questions.

The last two judicial virtues are the most definitely judicial virtues: judicial impartiality and judicial independency. Impartiality is a virtue that is pertinent for particular roles in society, especially those that imply functioning as a 'third party' with the authority to resolve conflicts between two or more parties. ${ }^{53}$ Judicial impartiality implies that a judge is disposed to distance himself from his attachments in daily life when addressing the case before him. An impartial judge disregards his personal make-up and is disposed to recognize and ignore considerations stem-

48 Under the heading of 'seriousness and prudence' the European Network of Councils for the Judiciary states that 'seriousness requires behaving respectfully during legal proceedings, being courteous, without excessive solemnity, and without inappropriate humour.' See 'Judicial Ethics Report 2009-2010: Judicial Ethics, Principles, Values and Qualities,' 67.

49 Solum, 'Virtue Jurisprudence. A Virtue-Centered Theory of Judging,' 186.

50 Terry A. Maroney, 'Angry Judges,' Vanderbilt Law Review 1207 (2012): 1214. In this article Maroney offers an interesting discussion of the phenomenon 'angry judges' in which the positive role of anger on the part of the judge is highlighted.

51 The Magna Carta of European Judges puts it as follows: A just judge aims to 'guarantee the very existence of the Rule of Law, and thus, to ensure the proper application of the law in an impartial, just, fair and efficient manner.' See 'Magna Carta of Judges (Fundamental Principles).'

52 Cf. David Wiggins, 'Neo-Aristotelian Reflections on Justice,' Mind 113(451) (2004): 481.

53 William Lucy, 'The Possibility of Impartiality,' Oxford Journal of Legal Studies 25 (2005): 6-7. 
ming from his possible interests, biases, passions, and subjective commitments. ${ }^{54}$ This of course is not tantamount to the ability of the judge to relinquish his experiences, commitments, and concerns, that is, to give up his personality. A judge cannot perceive well if he does not genuinely understand the meaning and the practical bearing of a wide range of phenomena and concepts such as discrimination, fraud or sexual abuse, and for this kind of knowledge he needs to have experience himself. ${ }^{55}$

Finally, the last virtue to be discussed is that of judicial independency. This virtue is closely linked to judicial courage. It implies that a judge is independent of and not influenced by external factors and pressures, be it from litigating parties, governmental bodies, lobbyists or from the public at large. According to 'The Bangalore Principles of Judicial Conduct' judicial independence comes down to 'not letting [one's] judgments be determined by external influences, inducements, pressures, threats or interference, direct or indirect, from any quarter or for any reason. ${ }^{56}$ Judicial independence is particularly called for in cases in which public opinion is rather strong, such as criminal cases against (alleged) sex offenders or murderers, immigration law cases or cases in which powerful parties are involved, such as the state itself. A judge who lacks this virtue may for instance fail to protect the right to religious freedom of a minority group out of fear for criticism, mockery, and other repercussions from the public at large.

So far the set of judicial virtues that I hold to be constitutive for moral quality. ${ }^{57}$ The virtues that are enumerated form a coherent whole and they are mutually supportive, or to use John McDowell's words: '[N]o one virtue can be fully possessed except by a possessor of all of them, that is, a possessor of virtue in general. ${ }^{58}$ If a judge lacks one of these virtues, all of them are in peril. Judges should thus possess all of said virtues up to a sufficient degree in order for adjudication to have moral quality.

54 Lucy, 'The Possibility of Impartiality,' 15.

55 Because perception is trained by actual experience, Aristotle was keen to stress that the elderly are most likely to have a sharp eye for practical matters. Cf. Aristotle, Nichomachean Ethics, 1143b10-14.

56 'The Bangalore Principles of Judicial Conduct.'

57 Note that judicial integrity is not mentioned here as a separate judicial virtue. I hold integrity to be a meta-virtue in the sense that it encompasses all others. See for an elegant and insightful philosophical analysis of the integrity of the judge Jonathan Soeharno, The Integrity of the Judge (Farnham: Ashgate, 2009). Also, we can now identify two differences between my approach and the one proposed by Lawrence Solum. First, I do not consider legal intelligence a separate judicial virtue, but rather see it as a precondition for the judicial virtues, most prominently that of judicial justice. Second, I assign to the virtue of judicial perception a more central role and also a different meaning than Solum's account of judicial wisdom - the judicial virtue that most resembles that of judicial perception. 
Sure, gradual differences do exist as to the relevance of each of these virtues for different judges, for instance for trial judges and appellate judges. ${ }^{59}$ Yet, we have no reason to assume that these differences are so fundamental that separate lists of virtues should be made for each of these specific judicial roles. For instance, at the outset the virtue of judicial perception seems more pertinent for trial judges than for appellate judges. Whereas it is part of the professional role of the first to determine the (relevant legal) facts of the case, the latter by contrast have only limited leeway for reviewing the facts. The role of appellate judges is mostly concerned with the question whether the law has been rightly applied by lower courts.

Nonetheless, the virtue of judicial perception is crucial for appellate judges as well. For any answer to the question whether the law has been rightly applied by a lower court and hence whether the applicable rules were ascribed the right meaning will always hinge on an interpretation of the facts as they are presented by lower courts. The meaning is necessarily established in the light of the case at hand and therefore it unavoidably involves interpretation of the facts of the case. In order for this interpretation to be of a certain quality appellate judges also do need the virtue of judicial perception in their professional and institutional context. Not in the least also because, as we have seen, this virtue pervades all the other judicial virtues. For an appellate judge to assess what for instance judicial courage demands in a concrete case implies that he is able to adequately grasp the relevant features of the case.

Before concluding this section certain implications of the virtue-centred approach that is proposed here, will be (further) explicated. The present approach assigns both a structural and constitutive role to the virtues for realizing moral quality. This makes it a truly virtue-centred approach rather than weakly virtue-centred. The latter view indicates that judicial virtues are assumed to play only an incidental role in realizing moral quality - in the rare and negligible cases in which settled law does not offer sufficient guidance to the judge - or it indicates that their role is merely an instrumental one. ${ }^{60}$

Conversely, a truly virtue-centred approach holds that a judge's professional character must always be of a certain quality and that for the vast majority of cases a

59 Barbara Herman has for instance questioned whether there exists enough unity between different courts for one list of judicial virtues to make sense. She states 'if there are radical differences, then there is room to question the transitivity of virtue from lower to higher courts.' See Barbara Herman, 'Comment on Gavion,' Southern California Law Review 61 (1988): 1663ff. See for this point also Solum, 'Virtue Jurisprudence. A Virtue-Centered Theory of Judging,' 193.

60 This strategy fits with what is known as the 'equity' tradition, a tradition that is well-entrenched in common law and civil law orders, and that to a large degree draws on a specific understanding of Aristotle's idea of equity (epikei). Within this tradition equity is understood as the standard that judges exclusively and incidentally apply as a correction to flagrantly unjust laws or as an amendment to law for the supposedly limited number of situations in which it shows 'gaps' think of Dworkin's 'holes in a doughnut.' This idea has been qualified as the 'doctrine of equitable discretion.' See for discussions of this doctrine in both civil law and common law traditions among others Allan Beever, 'Aristotle on Equity, Law, and Justice,' Legal Theory 10(1) (2004); Robert A. Shiner, 'Aristotle's Theory of Equity,' Loyola of Los Angeles Law Review 26 (1994). 
modicum of intelligence will not do for a judge to adequately deal with a case. ${ }^{61}$ The main argument supporting this view has to do with the pervasive role that the present approach assigns to judicial perception. This role is not instrumental, i.e. as a mere means to arrive at the judicially right decision, but rather it is constitutive for rightness; a 'right' decision cannot coherently be understood independently of the judge's character. It can in any case not be deduced either from the 'facts' or 'features' characterizing a legal case or from rules or principles. As to the first, again, judicial reality does not impose itself on the mind of the judge. Thence on their own 'the facts' of a legal case cannot do any justificatory work. Nor can a right decision be deduced from legal rules and principles. As pointed out earlier, before the judge can think of bringing a general concern to bear on the legal case - be it a rule or principle - he must already have a take on which features of the situation before him are salient and 'pull for' certain legal concerns. For this kind of knowledge a judge needs to have perceptive qualities, and thus - as was argued above - a certain kind of character. It is for this reason that the judge himself is in the end constitutive for what rightness entails, also for run of the mill cases. For these cases pertain to the practical realm as well; they invite a judge to adequately grasp the particulars and on that account they do require his 'lens of character.' What is more, to conceive of the virtues as merely instrumental or incidental also means to ignore that expressions of the virtue judicial perception can be of value in their own right.

Being truly virtue-centred, another implication of the present approach is that it understands the relevant domain for the moral evaluation of adjudication rather broadly. Actual judicial decisions are but one aspect of adjudication that is relevant for assessing its moral quality. ${ }^{62}$ Beside these decisions all kinds of voluntary and involuntary, spontaneous and emotional responses of judges both in and out of court are part of the morally relevant landscape. For instance, a judge who regularly makes discriminatory jokes at social gatherings may be a threat to moral quality because of what seems a defect in his professional character. But also all kinds of considerations in sentences that are not directly related to the actual decision may be indicative for (a lack of) moral quality. Think of the sensitivity that a judge expresses by particular 'obiter dicta' - a phenomenon that is often deemed legally irrelevant -: these can be an indication of him possessing certain virtues.

Because we put so much emphasis on judicial virtues for the realization of moral quality we need to address the issue of how these virtues are developed. In a virtue-ethical approach training in practice is key for the realization of moral

61 At this point I thus disagree with the idea that '[...] over large stretches of the law anyone with a modicum of intelligence can work out what the law is or requires [...].' Cf. Anthony Duff, 'The Limits of Virtue Jurisprudence,' Metaphilosophy 34(1/2) (2003), 221.

62 For this point I draw on Iris Murdoch's view on the broad scope of 'data' that she deems relevant for moral evaluation. Her critique on mainstream moral theory is that it exclusively focuses on the quality of overt and discrete choices and in so doing wrongly expels from the moral landscape 'the inner monologue and its like, but also overt manifestations of personal attitudes, speculations, or visions of life such as might find expression in talk not immediately directed to the solution of specific moral problems.' Cf. Murdoch, 'Vision and Choice,' 79. 
quality. The image of a six-pack of judicial virtues was used to point to an important analogy between the development of muscle-power and the development of virtues. Similar to the development of muscle-strength, developing one's professional character is a piecemeal, a demanding and time consuming undertaking that progresses slowly and requires regular practice. In the end this development should be such that the affective and intellectual aspects of virtue harmoniously work together. For this process to succeed (aspirant) judges largely depend on there being sufficient 'virtue-friendly' institutions and practices available in which the judicial virtues can be learned and trained. ${ }^{63}$ Of course, a crucial institution is the judiciary itself, including the special professional education and training it offers to aspirant judges. This institution and the education and training it offers should be of a certain quality if it is to offer the necessary directional indicators, ambiance, and support for (aspirant) judges to indeed develop the judicial virtues.

On the negative side, obviously the judiciary should be free from factors that impede the development of judicial virtues, or that more likely contribute to the training of judicial vices. ${ }^{64}$ Efficiency criteria in terms of time and financial means can be such potential obstacles that arguably contribute to developing vices rather than virtues. ${ }^{65}$ Such criteria may force judges to cut corners, curtail investigations, interrogations, and reflections and dedicate less time to a case than they deem fit. These factors may also result in judges only 'reviewing' draft sentences that the court clerk has prepared, without him being confronted with the 'facts' of the case and having dealt with the difficulties of legally qualifying these facts. If the judge only reviews draft sentences, in the words of Kronman this 'will entail a reduction in the demand that his or her own work makes on the judge's imaginative powers and the consequent enfeeblement of these powers themselves. ${ }^{66}$

Other potential obstacles in the professional environment of the judge for the formation of the judicial virtues are what Buchanan calls 'elite-culture, ${ }^{\prime 67}$ 'surplus

63 Cf. Michael Oakeshott, 'The Tower of Babel,' in Anti-Theory in Ethics and Moral Conservatism, ed. Stanley G. Clarke et al. (New York: State University of New York Press, 1989), 188.

64 See for a radical but telling critique on developments in the judiciary in the United States that threaten the formation of practical wisdom on the part of the judge Anthony T. Kronman, The Lost Lawyer: Failing Ideals of the Legal Profession (Cambridge, MA: Belknap Press of Harvard University Press, 1993), 315-52.

65 This is of course not to say that constraints in terms of time and finances should be absent in the organisation of the judiciary. However, they should simply not thwart the possibility of exercising the judicial virtues.

66 See for this point also Kronman, The Lost Lawyer, 326.

67 Buchanan points here to a culture 'within an institutional context in which a certain occupational group has attained elite status, thereby receiving special privileges that insulate the group's members from criticism and that systematically impede the functioning of virtues that may operate quite effectively in areas of the elite's lives in which the professional role is not implicated.' Cf. Allen Buchanan, 'Social Moral Epistemology,' Social Philosophy \& Policy Foundation 19 (2002): 133. 
status-trust, '68 and 'surplus epistemic deference' ${ }^{\prime 69}$ respectively. These are tendencies that are inherent to every professional context and that put the process of judicial character building in peril. A virtue-ethical approach implies that such tendencies are counterbalanced, and that by implication the discipline of social moral epistemology is highly relevant, a discipline that among others studies the social and institutional conditions under which the exercise of virtues can flourish. ${ }^{70}$

Evidently, law school is another crucial institution for the development and training of judicial virtues. In order for students to become virtuous judges, to phrase Sullivan, 'legal education needs to attend very seriously to its apprenticeship of professional identity. ${ }^{71}$ Law school should contribute to the character building of their students. ${ }^{72}$ For this purpose ideally it pays ample attention to the establishment of the facts of a case and to the 'deed' of legal qualification as core issues in the curriculum. Ideally it also fosters the formation of courage, independency and impartiality, for instance by confronting students with all kinds of psychological knowledge as regards the influence of group dynamics and institutions on human behaviour and by allowing them to practice adequately coping with such obstacles to acting virtuously, which are always present.

It goes without saying that 'background' practices such as family life, other social practices and primary and secondary education and socialization are crucial for

68 Buchanan, 'Social Moral Epistemology,' 135. Buchanan defines surplus-status trust as 'status based trust that is accorded to the wrong people or is excessive.'

69 Buchanan, 'Social Moral Epistemology,' 136. Surplus epistemic deference is, according to Buchanan, 'either deference that is misplaced, as when a person or a group is regarded as a reliable source of truths about matters on which he or it is not, or excessive, as when there is an overestimation of a person's or group's reliability as a source of truths.'

70 Buchanan rightly made clear that both proponents of moral theory and of virtue ethics have not paid sufficient attention to the importance of social moral epistemology in order to guarantee that people act rightly. He defines social moral epistemology as 'the study of the social practices and institutions that promote (or impede) the formation, preservation, and transmission of true beliefs so far as true beliefs facilitate right action or reduce the incidence of wrong action. A special department of social moral epistemology is the study of the social practices and institutions that promote (or impede) the functioning of moral virtues so far as their functioning depends on true beliefs.' Buchanan, 'Social Moral Epistemology,' 126.

71 William M. Sullivan, 'Professional Identity and Purpose,' in Educating Lawyers: Preparation for the Profession of Law, ed. William M. Sullivan et al. (San Francisco: Jossey-Bass, 2007), 128.

72 See for an inspiring article on the importance of focusing on character in legal education Timothy Hall, 'Moral Character, The Practice of Law, and Legal Education,' Mississippi Law Journal 60 (1990). A virtue-ethical approach would endorse 'the pervasive method,' a method in which issues of ethics, social psychology and positive law are integrated. It rejects the kind of legal education that exclusively focuses on the development of legal intelligence and limits the curriculum to the development of knowledge of the law as a settled and explicit body of principles, rules and jurisprudence, as if these were distinct and independent authorities for practical knowledge that have value independently of the situations in which these principles and rules will be used. Sullivan ('Professional Identity and Purpose,' 144) has put this point nicely: 'Intellectual mastery alone is, indeed, always a possible pathology of schooling - one that can subtly subvert the best efforts of professional schools by displacing the goal of learning the profession with a more selfcontained academic aim of technical virtuosity, detached from attention to the ends of legal reasoning.' See for a discussion of this 'pervasive method' p. 151-52 of the same publication. 
the development of the judicial virtues as well. ${ }^{73}$ They should provide a preliminary contribution to the formation of the relevant judicial virtues by for instance paying attention to the social and personal reality of citizens belonging to different groups and walks of life and by offering room for a critical stance to inherent biases and inequalities that figure in society. Formation and development of judicial virtues in a culture that is highly discriminatory is next to impossible, or at least faces an obstacle that is difficult to overcome.

So, by now it will be clear that becoming a virtuous judge boils down to a continuous process of (self-) improvement which starts long before one actually becomes a judge. As Julia Annas succinctly says: 'We don't become virtuous without effort, nor overnight. ${ }^{.74}$

Finally, we must of course address the question how the present approach relates to the ideal of the rule of law. Brian Tamanaha has put this ideal as follows: 'The rule of law, at its core, requires that government officials and citizens are bound by and act consistent with the law. ${ }^{75}$ Sure, if we interpret this requirement strictly, as a requirement of legality, a virtue-centred approach does not live up to it. It understands adjudication as primarily determined by judges and not so much by rules or principles and it assigns an important role to the judge's emotional and affective state, aspects that by definition cannot directly be regulated by rules or principles.

However, I think in this respect there is no reason to lament the apparent loss. For one thing, a virtue-ethical approach does assign an important role to explicit rules and principles. ${ }^{76}$ They function as rules of thumb, as summaries of a wide range of good judicial decisions. They are held to be of practical use, particularly for junior judges who need to develop their professional character, and for judges who are insecure in a concrete case, for instance because the case involves a legal field that they are not well acquainted with. More generally, these resources can function as helpful safeguards in situations where biases lurk and rationalizations loom. As such they are valuable tools for judges to critically assess their own practice. In addition codified rules and principles offer publicly accessible concepts in terms of which judges can - albeit only partially - explain and defend their decisions. They also function 'as an indication of what society may expect from the judiciary and from judges' conduct.' They 'allow (...) society insight into the way in which judges perceive their role. ${ }^{, 77}$ The primacy that a virtue-centred approach assigns to the virtues is thus not tantamount to denying the importance of settled, codified law and codes of judicial conduct.

But, perhaps more importantly, a virtue-centred approach is in fact responsive to the concerns underlying the ideal of the rule of law, that is, to prevent abuse and

See for a neo-Aristotelian approach to legal education for instance Martha C. Nussbaum, 'Cultivating Humanity in Legal Education,' The University of Chicago Law Review 70(1) (2003).

74 Cf. Annas, The Morality of Happiness, 57.

75 B.Z. Tamanaha, 'A Concise Guide to the Rule of Law,' in Florence Workshop on The Rule of Law, ed. Neil Walker et al. (Florence: Hart Publishing, 2007), 3.

76 Cf. Nussbaum, 'The Discernment of Perception: An Aristotelian Conception of Private and Public Rationality,' 93-96.

77 See 'NVvR Guide to Judicial Conduct'. 
arbitrary exercise of power. By proposing an ideal of a good judge in terms of the judicial virtues it protects citizens against the arbitrary influence of the subjectivity of the judge, an influence that rule- or principle-based approaches to adjudication underestimate.

In addition a virtue-ethical approach adds to the intelligibility and to the predictability of adjudication in that a virtuous judge will try to honour the particulars by deploying a range of aforementioned thick value concepts. These concepts are highly concrete, i.e. they have a 'contour,' a locally intelligible elaboration with which citizens are also familiar. ${ }^{78}$ This shared social context that the judge brings to bear in a concrete case actually adds to the predictability of legal decisions, also as regards the kinds of considerations that a judge will hold to be relevant. Precisely because judges use these thick concepts they allow citizens to make sense of the decisions in a relatively direct way, thereby compensating for the fact that written law is often largely inaccessible to average citizens and that most citizens simply do not know the law.

\section{Respect in adjudication: the judge as a civic friend ${ }^{79}$}

Unfortunately, we cannot rest content with the virtue-centred approach as it is elaborated and defended above as an account of moral quality of adjudication. On its own this approach violates a demand that, at least for modern constitutional legal orders, is crucial for the legitimacy of the exercise of state power: the demand of equal respect. For it is generally agreed upon that in a liberal society the exercise of state power in order to be legitimate must be based on reasons that all (affected) citizens can endorse. As a practice in which one group of citizens exercises state power over others in a rather direct way, it goes without saying that this demand is rather urgent for adjudication as well.

As it stands the present virtue-ethical approach cannot meet the demand of equal respect. This is due to the fact that in this approach a right judicial decision is the decision that a virtuous judge would characteristically take under the given circumstances. ${ }^{80}$ Rightness thus has an inherently personal touch to it. Each virtuous judge may have his own individual way of perceiving and valuing the relevant facts and of assigning weight to the relevant (legal) considerations. By implication, within this approach opposite judicial decisions in seemingly similar cases can both be right. These kinds of 'inconsistencies' are not seen as failures of rationality, but rather as expressions of it. Thence, disagreements about what the right judicial decision amounts to are not rationally and conclusively solved

79 Elements of this discussion of civic friendship also appeared in Iris van Domselaar, 'A NeoAristotelian Notion of Reciprocity: About Civic Friendship and (the Troublesome Character of) Right Judicial Decisions,' in Aristotle and the Philosophy of Law: Theory, Practice and Justice, ed. Liesbeth Huppes-Cluysenaer et al. (Dordrecht: Springer, 2013).

80 Cf. Rosalind Hursthouse, On Virtue Ethics (Oxford: Oxford University Press, 1999), 28; Solum, 'Virtue Jurisprudence. A Virtue-Centered Theory of Judging,' 202-4. 
through the application of an external measure. Such disagreements cannot be understood as being concerned with differences of choice, given the same valueneutral facts. Rather, they often imply a difference of vision. ${ }^{81}$ Consequently, their resolution most of all calls for a 'skilful presentation of an instance' and persuasion. ${ }^{82}$

However, if we take the demand of equal respect seriously mere reference to the notion of a virtuous judge as a justificatory ground for why a judicial decision is right will not suffice as a reason for a 'losing' citizen to accept the burden of a particular decision. ${ }^{83}$ This notion is too elitist or esoteric a reason; it presumes that the losing citizen will have some kind of awe for judges in general or does not consider himself as worthy of respect. ${ }^{84}$ It implies that citizens simply have to rely on judicial decisions to be right, because judges are to a sufficient degree 'virtuous' and thus have to give up on the value of their own take on things. They in any case are not provided a reason to accept the decision that makes sense to them, as concrete individual citizens who deserve equal respect.

From the viewpoint of equal respect this is problematic, all the more so because a virtue-ethical approach implies that a particular decision could have turned out otherwise, had another (virtuous) judge decided the case. The question why a negatively affected citizen has a genuine reason to accept this particular decision is as yet left unanswered.

To at least partially fill this moral lacuna of the present virtue-ethical approach I propose the Aristotelian concept of civic friendship as a valuable complement to the notion of a 'virtuous judge' and the aforementioned set of judicial virtues. ${ }^{85}$ The idea is then that in order for adjudication to have moral quality a judge should not only be (sufficiently) virtuous, but he should also decide as a civic friend.

In Aristotle's philosophy friendship (philia) refers to a social relation in which the parties involved have a genuine and effective concern for one another. ${ }^{86}$ Friendship is characterized by mutual well-wishing (eunoia) or 'good will between recip-

81 Murdoch, 'Vision and Choice,' 82.

82 McDowell, 'Virtue and Reason,' 65.

83 Solum, 'Virtue Jurisprudence. A Virtue-Centered Theory of Judging,' 201.

84 Peter Simpson brought a similar point in more general terms against Aristotle's virtue ethics: 'Aristotle's court of appeal is not reason or argument but opinion - and not the opinion of all, but only of a few.' Cf. Peter Simpson, 'Contemporary Virtue Ethics and Aristotle,' Review of Metaphysics 45(3) (1992): 513.

85 There is little literature on the value of the concept of friendship for law and adjudication. See for an important article on this topic Ethan J. Leib, 'Friendship \& the Law,' University of California Law Review 54 (2006). For a discussion of the relevance of Aristotle's concept of civic friendship for modern liberal political theory see Eleni Leontsini, 'The Motive of Society: Aristotle on Civic Friendship, Justice and Concord,' Res Publica 19(1) (2013). For a more sceptical position in this regard, see Simon Hope, 'Friendship, Justice and Aristotle: Some Reasons to be Sceptical,' Res Publica 19(1) (2013). Within the scope of this article I will not go into the objections that are made against assigning a role to Aristotle's civic friendship in liberal political theory. I do not think these objections are fundamental, but surely they do deserve to be addressed.

86 John M. Cooper, 'Aristotle on the Forms of Friendship,' in Reason and Emotion: Essays on Ancient Moral Psychology and Ethical Theory, ed. John M. Cooper (Princeton, NJ: Princeton University Press, 1999), 312. 
rocating parties' of which the parties are aware in such a way that a sense of mutual trust is fostered. ${ }^{87}$

Friendship in this Aristotelian sense points to a complex and delicate combination of self-seeking and selfless concern for the good of the other. ${ }^{88}$ On the one hand it serves the self-interest of each of the parties involved because of the overall good that is realized through the relation on the long term. The profitability of this relation for each party then lies in its overall fabric, not so much in each and every particular action rendered. ${ }^{89}$ On the other hand, friends typically bind themselves, within certain limits, to sacrifice their own particular interests for one another. ${ }^{90}$ Friendship means 'that the fact that the other person needs or wants, or would be benefited by something is taken by the agent as by itself a reason for doing or procuring that something (...). ${ }^{91}$

Aristotle understands civic friendship as a species of advantage-friendship, ${ }^{92}$ the advantage being the overall good that living together in society brings to all citizens, i.e. the opportunity to flourish. ${ }^{93}$ He holds that once citizens have experienced the benefits of living in a political community they start caring for one another's good. ${ }^{94}$ In a political community 'animated by civic friendship, each citizen has a certain measure of interest in and concern for the well-being of each other citizen just because the other is a fellow-citizen. ${ }^{95}$ Thus, in a society that indeed seeks to serve the good of each and every citizen, it makes sense to conceive of adjudication as a practice in which judges and citizens confront one another not only in their specific institutional roles, but also as civic friends. In this way the idea of equal respect can be accounted for in the context of adjudication.

For a judge the attitude of a civic friend implies that he has an emphatic attitude towards the concrete good that is at stake for the citizens involved. Such a judge

87 Aristotle, Nichomachean Ethics, 1155b33-34.

88 Cooper, 'Aristotle on the Forms of Friendship,' 317. Friendship in this Aristotelian sense does not - at least not exclusively - refer to our modern way of understanding friendship as an intimate, highly personal relationship. Rather, it equally applies to the relation between parents and children, siblings, spouses, business partners, members of religious communities, social clubs, political parties, and between citizens. It equally covers relations that are deep, shallow, lasting or transitory.

89 Cooper, 'Aristotle on the Forms of Friendship,' 327.

90 In the words of Cooper, as civic friends ' $\mathrm{t}$ ] hey are accommodating rather than suspicious, anxious to yield a point rather than insisting on the full letter of their rights whenever some dispute arises.' John M. Cooper, 'Aristotle on the Forms of Friendship,' in Reason and Emotion: Essays on Ancient Moral Psychology and Ethical Theory, ed. John M. Cooper (Princeton, NJ: Princeton University Press, 1999), 333.

91 Cooper, 'Aristotle on the Forms of Friendship,' 314.

92 Aristotle distinguishes three kinds of friendship: advantage friendship, pleasure friendship and character friendship. Advantage friendship works to the personal advantage of the friends involved, pleasure friendship is based on the pleasure it gives the friends, and character friendship is based on goodness of character. Cf. Aristotle, Nichomachean Ethics, 1156a6-b32.

93 Aristotle, Nichomachean Ethics, 1160a9-14; Cooper, 'Aristotle on the Forms of Friendship,' 333.

94 Cooper, 'Aristotle on the Forms of Friendship,' 323.

95 Cooper, John M., 'Political Animals and Civic Friendship,' 371. 
will seek to grasp and serve their good in the best possible way - a way that is compatible with all the other concerns he feels bound to address. ${ }^{96}$ This in any case means that he makes a genuine effort to limit the violations of the concrete interests of the citizens involved. As a result, judicial sentences are not only the expression of the judge's virtues, but also the result of his well-wishing so that citizens can be sure that their concrete interests are indeed taken seriously.

Thence from the viewpoint of civic friendship we may be able to identify a range of utterances in actual legal sentences as potential expressions of judicial friendship, of well-wishing by the judge. These are the considerations in which a judge addresses the concrete good of the litigating parties where this is not indicated by settled law. ${ }^{97}$ Rather than ignoring them as negligible non-legal phenomena or legally non-binding, as it is often done, these expressions should perhaps be appreciated, or 'rehabilitated' if you wish, as part of the moral backbone of adjudication. They can be valued as ways of morally coming to grips with the relational dimension of adjudication and thence with the demand of equal respect.

By the same token, citizens who are involved in legal proceedings should have a 'civic friendly' or accommodating attitude as well. By their cooperative attitude and by accepting the judicial decision litigants or defendants can express their commitment to the common good, to the political order and the values it aims to protect. In this way they show themselves to be responsible citizens. ${ }^{98}$

So far this proposal has been rather abstract. I will therefore further explicate how civic friendship may work out in the context of adjudication by means of an example. The example is the case of $\mathrm{D}$, a widow of almost eighty years old, whose husband passed away a decade ago and whose sole companions are her two dogs. Due to D's precarious financial situation she had to sell her house and rent a smaller apartment. ${ }^{99}$ However, after moving to this new apartment the dogs got rather disordered. They barked often and loudly and sometimes urinated on the carpet in the public hallway. They were used to a garden and the new apartment does not have one. Within a few days $\mathrm{D}$ received complaints from her neighbours asking her to get rid of the dogs. With pain in her heart she gets rid of one of the dogs, but keeps the oldest dog, the one that her late husband gave to her as a birthday present. Unfortunately, disordered as it already was, this dog is now even more upset and keeps barking and urinating in the public hall. As D is very determined to keep her dog, the neighbours file suit against $\mathrm{D}$, demanding that

96 True, one could hold that a virtuous judge is already judicially perceptive. But this is not the same as being fully engaged with the concrete litigating parties and being concerned with their concrete good, because of the very fact that it is their good.

97 Further research is needed to for instance establish to what extent this concept sheds new light on what has generally been qualified as 'obiter dicta.'

98 Surely it remains to be seen what implications the idea of civic friendship has for all kinds of roles that are involved in legal proceedings.

99 See for similar cases Rb. Dordrecht, September 25, 2008, ECLI:NL:RBDOR:2008:BF2284; Rb. Leeuwarden, October 25, 2011, ECLI:NL:RBLEE:2011:BU2511; Hof Den Haag, March 12, 2013, ECLI:NL:GHDHA:2013:BZ6556; Hof 's-Hertogenbosch, December 28, 2010, ECLI:NL:GHSHE: 2010:BP0257. 
she gets rid of the dog because of the hinder and nuisance it causes, with a fine of 50 euro a day in case of violation.

Now, from a virtue-ethical perspective the judge has to respond in the way a 'virtuous judge' - the one who has developed all six judicial virtues - would. He has to ponder and value all the particularities of the case against the background of settled law and background values of political morality and decide whether the hindrance justifies restricting D's liberty to keep her dog.

However, if the judge decides to grant the request, in the end a virtue-ethical approach has nothing more to offer but this reference to the 'virtuous judge.' D simply has to accept the 'privileged' perception of the judge without her being provided a ground why as an equal citizen she also has a reason to accept the decision, while by the same token another judge could have taken another decision.

By contrast, if the judge's perception and his way of responding to the case are channelled by the attitude of a civic friend, D can be sure that the judge has really 'faced' her, that he has taken her specific interests as concrete individual citizen seriously. Such a judge will be likely to see the urgency of the interests at stake for $\mathrm{D}$, such as avoiding loneliness, social isolation, and mental decay. A judge who wishes $\mathrm{D}$ well will take into account the suffering caused to D if she has to give up on the dog she is so much attached to, also due to its connection with her late husband. Indeed, this empathic understanding could even lead the judge to decide to reject the request of the neighbours and to allow $\mathrm{D}$ to keep the dog. In any case, if the judge decides as a civic friend $D$ can be sure that the decision will be an attempt to find an equilibrium between her interests as a unique citizen and the good of society. ${ }^{100}$

Of course, a crucial question that arises at this point is whether this idea of civic friendship makes sense for all kinds of legal cases. ${ }^{101}$ What about the cases in which citizens are accused of having seriously violated the basic interests of others? ${ }^{102}$ In dealing with this point it is important to take into consideration that the advantageous character of a civic relation does not directly 'evaporate' when citizens commit crimes or other kinds of unlawful wrongdoings. As said, for friendship to exist not each and every activity needs to be advantageous to the parties involved. Failures and wrongdoings are part of practices that constitute friendship. ${ }^{103}$

What is more, upholding a relation of civic friendship with a wrongdoer can be profitable, for it may further the likelihood of a future cooperative attitude of the 'failing' citizen. The wrongdoer may still be able to perform or continue to perform several social roles and thus contribute to the general good. ${ }^{104}$

100 Sure, one may object that the interests involved in this case are too trivial to function as a genuine support for the abstract claim. Whether such an objection is valid is open for discussion, but I think it is not. Also, if this example already arouses some weak intuitions that support the argument, then all the more so will cases that involve even more fundamental interests.

101 I am indebted to Professor Lawrence Solum for signalling this question.

102 These cases may fall in the domain of criminal law, but may also come up in other areas of law, like tort cases in civil law or negligence and nuisance cases in environmental law.

103 Cf. Cooper, 'Aristotle on the Forms of Friendship,' 312.

104 Of course, this point is hypothetical and it needs further elaboration and empirical support. 
In addition, to approach citizens who have committed crimes or other wrongdoings as civic friends may have epistemological value for society as a whole. A sympathizing attitude enhances our understanding of what citizens in general need in order to be able to become good citizens, because it 'creates incentives (...) to think hard about those circumstances, so that we do not put people under pressures that many normal agents cannot stand.' ${ }^{105}$

Thence, the provisional answer to the question whether the concept of civic friendship applies even in cases of grave wrongdoings must be affirmative. Again, what matters for civic friendship is the profitability of the overall fabric of the civic relation. ${ }^{106}$ The judge can confront the wrongdoer with the conditions of civic friendship and hold him responsible according to these conditions. He can highlight the fact that the wrongdoer is part of a practice that aims to serve the good of society, including his good and the good of his fellow-citizens. In this way adjudication provides the wrongdoer with a context to reflect on his actions and measure them against a standard that is in a way his own.

It goes without saying that in extreme cases the relation of civic friendship does come to an end, simply because the idea of mutual well-wishing is off mark. This may be so in case the wrongdoer lacks the necessary cognitive and moral capacities to be effectively committed to the good of others, or if he has structurally and genuinely expressed that he has no concern for the good of others or for society. The judge then still has to decide as a virtuous judge, but he need not act as a civic friend.

Finally, we should bear in mind that a virtuous judge who at the same time fulfils his role with the attitude of a civic friend may face genuine judicial dilemmas, not in the least also because the considerations stemming from different virtues may genuinely conflict. These conflicts cannot by definition be prevented, for they are not necessarily due to mistakes in the law, in the legal system or in the reasoning of the judge. They belong to the very nature of the practical realm. Now if any of these conflicts occur and the interests at stake are fundamental, a judge may find himself confronted with having to make a tragic legal choice, a choice that comes with a genuine moral loss, with judicial wrongdoing without the actual choice being the wrong one. The account of moral quality that is proposed here is therefore far from morally reassuring. It understands adjudication even in its ideal form as vulnerable for tragedy, for leading to judicial wrongdoing and genuine tragic losses. ${ }^{107}$

105 Martha C. Nussbaum, Martha C., 'Victims and Agents. What Greek Tragedies can Teach us about Sympathy and Responsibility,' Boston Review, February/March (1998).

106 Cooper, 'Aristotle on the Forms of Friendship,' 327.

107 In this context I will not delve further into the central features of a tragic legal choice. See for a discussion of the concept of a tragic legal choice Iris van Domselaar, 'Tragic Choice as a Legal Concept,' Archiv für Rechts- und Sozialphilosophie 119 (2010). 


\section{Conclusion}

We have discussed a proposal for a specific version of a truly virtue-centred approach to adjudication. Judicial virtues are held to be both constitutive and indispensible for moral quality even in run of the mill cases, not just incidentally. More specifically the claim is that judges should in any case possess the following six-pack of judicial virtues for adjudication to have moral quality: judicial perception, judicial courage, judicial temperance, judicial justice, judicial impartiality and judicial independency. A rather prominent role is assigned to the virtue of judicial perception. If anything, a virtuous judge is a perceptive judge.

Subsequently, I argued that if a virtue-centred approach would exclusively focus on the notion of the virtuous judge as a justificatory ground for judicial decisions, it could not live up to the demand of equal respect. The idea of a virtuous judge is not by itself a sufficiently satisfying reason as to why a 'losing' citizen should accept the decision. In order to fill this moral lacuna, the Aristotelian concept of civic friendship was proposed as a complement to said judicial virtues. For citizens who participate in a legal proceeding to receive equal respect and their due, a judge should not only possess the judicial virtues, he should also have the attitude of a civic friend. 